\title{
Emergency Room Disaster Preparedness Management of Mitra Delima Hospital in COVID-19 Pandemic
}

\author{
Tommy Kristanto $^{1 *}$, Aurick Yudha Nagara ${ }^{2}$, Dhian Kartikasari ${ }^{3}$ \\ ${ }^{1}$ Hermina Hospital, Purwokerto, Central Java, Indonesia \\ ${ }^{2}$ Faculty of Medicine Universitas Brawijaya, Malang, East Java, Indonesia \\ ${ }^{3}$ Department of Public Health, Faculty of Sport Science, Universitas Negeri Malang, Malang, East Java, Indonesia \\ *Corresponding author. Email: dhian.kartikasari.fik@um.ac.id
}

\begin{abstract}
COVID-19 still become a major problem for the entire world population, with the number of cases reaching 46 million as of October 2020. The COVID-19 widespread is one of a kind since of the scale, speed of spread, and need of logical information related to this unused disease. Hospitals, especially ER as an entrance for patients, are required to face various challenges related to this pandemic. However, the health service resilience system facing the COVID-19 pandemic is still looking for its optimal form so it is interesting to being researched further. Research was conducted using descriptive methods in ER Mitra Delima Hospital, type C private hospital which is non COVID referral. The research data was obtained from interviews with the Head Deputy of ER, COVID patient reports, policy changes and Operational Standards Procedures (SOP) as well as data on the use of Personal Protective Equipment (PPE) from MarchAugust 2020. The COVID-19 pandemic led ER Mitra Delima Hospital to make several policy changes by changing patient flow, layout and screening of IGD to COVID and non-COVID, the addition of ER beds and staff, and changes to referral SOP and PPE to improve patient safety and ER personnel of Mitra Delima Hospital. Most health services, especially ER Mitra Delima Hospital, will face an increase in COVID-19 patients and must anticipate the consequences, including increasing the number of beds, personnel, and policy changes to guarantee the commitment of hospital management staff in order to improve the hospital's resilience to disasters, promote effective leadership, and provide a more structured communication path for the community and policy makers.
\end{abstract}

Keywords: COVID-19, disaster preparedness management, emergency room

\section{INTRODUCTION}

Disaster incidents are one of the most endangering events and emergency solutions are needed because of their sudden occurrence. Natural or unreal disasters will interfere with the activities of some organizations reminiscent of tending facilities. Typically, the capability of those facilities might not be ample to combat the physical and money harm they'll cause. though the flexibility to be prepared for disasters varies by country, it is aforementioned that within the last century, once the frequency and devastating effects of disasters have step by step increased, no country is absolutely ready and safe [1].

The current coronavirus disease 2019 (COVID-19) caused by coronavirus 2 (SARS- CoV-2) is spreading globally at an accelerated rate. World Health Organization (WHO) was declared COVID-19 as a pandemic on March 11, 2020. As of 1 November, about 46 million cases and 1.2 million passings have been detailed all-inclusive. Indonesia detailed around 24.000 unused cases ( 88.1 per 1 million populace) within the final past 7 days and over 410.000 aggregate cases to date [2].

Due to the one of a kind challenges of the COVID-19 widespread and the fast spread of contamination, the Indonesia therapeutic community, for case, Mitra Delima Hospital, must adjust and actualize rapidly evidencebased best hones that are planned to progress quiet care as well as the restorative community's well-being and versatility. Be that as it may, a far-reaching selection of evidence-based hone rules from national restorative social orders can take a long time. Unused evidencebased COVID-19 hones must be actualized in weeks [3]. In these circumstances, wellbeing care experts confront a number of complexities, counting the got to make basic 
choices in quickly changing and in some cases equivocal settings. They must oversee data over-burden coupled with extreme time weights, error-prone circumstances, unfavorable physical conditions, execution weights, and issues coming about from the require for different people from distinctive foundations to work viably [4].

Mitra Delima Hospital is C-type, private hospital, located in South Malang which "forced" to adapt during this COVID-19 pandemic. Despite being non COVID patient referral hospital, the ER of Mitra Delima Hospital has treated approximately 485 patients with suspected and 4 confirmed cases of COVID-19 since March-August 2020. In arrange to supply information on the hospital readiness and versatility of its wellbeing frameworks amid the COVID-19 widespread, we depict, at the clinic level, the key components of the reaction to COVID-19, counting the challenges and issues to expect taking after the involvement of ER Mitra Delima Hospital.

\section{METHOD}

Research was conducted using descriptive methods in ER Mitra Delima Hospital, type C private hospital which is non COVID referral. The research data was obtained from interviews with the Head Deputy of ER, COVID patient reports, policy changes and Operational Standards Procedures (SOP) as well as data on the use of Personal Protective Equipment (PPE) from MarchAugust 2020.

\section{RESULTS AND DISCUSSION}

Table 1. Challenges encountered by the hospital and local solutions found as hospital preparedness management

\begin{tabular}{|c|c|}
\hline Challenges & $\begin{array}{l}\text { Local Solutions Found as Hospital } \\
\text { Preparedness Management }\end{array}$ \\
\hline $\begin{array}{l}\text { Management of } \\
\text { suspected and } \\
\text { confirmed patient } \\
\text { with COVID-19 }\end{array}$ & $\begin{array}{l}\text { a. Placing triage place outside ER } \\
\text { b. Implementing COVID screening } \\
\text { tools in triage } \\
\text { c. Divide ER room into COVID and } \\
\text { non-COVID to minimize the } \\
\text { spread of infection } \\
\text { d. Training frontline healthcare } \\
\text { workers on the management of } \\
\text { COVID-19 }\end{array}$ \\
\hline $\begin{array}{l}\text { Managing and } \\
\text { taking care of ER } \\
\text { healthcare worker }\end{array}$ & Using level 2+ PPE \\
\hline $\begin{array}{l}\text { Expanded require } \\
\text { for health } \\
\text { workers }\end{array}$ & $\begin{array}{l}\text { Mobilization staff inside the pool of } \\
\text { hospital (case: included healthcare staff } \\
\text { to ER from the internal unit) }\end{array}$ \\
\hline $\begin{array}{l}\text { Increasing the } \\
\text { availability of } \\
\text { beds }\end{array}$ & $\begin{array}{l}\text { Added more standby beds in ER (from } \\
7 \text { to } 11 \text { beds) due to dividing ER room }\end{array}$ \\
\hline Policies & $\begin{array}{l}\text { a. Expecting the joins between pre- } \\
\text { hospital and hospital care by } \\
\text { recording and minimizing holding }\end{array}$ \\
\hline
\end{tabular}

\begin{tabular}{|c|c|}
\hline Challenges & $\begin{array}{l}\text { Local Solutions Found as Hospital } \\
\text { Preparedness Management }\end{array}$ \\
\hline & $\begin{array}{l}\text { up time for each phone referral of } \\
\text { COVID-19 cases } \\
\text { b. Regularly gives vitamins and } \\
\text { checkup rapid antibody to ER } \\
\text { personnels } \\
\text { c. Local adjustment of national and } \\
\text { international protocols } \\
\text { d. Normal emergency gatherings } \\
\text { including healthcare laborers, } \\
\text { head of the crisis office, and } \\
\text { regulatory staff to guarantee a } \\
\text { comprehensive and collective } \\
\text { technique } \\
\text { e. Having screening rapid antibody } \\
\text { test for COVID-19 patients }\end{array}$ \\
\hline
\end{tabular}

\subsection{Establishing the clinical management of suspected or confirmed patients with COVID-19}

Advising all the healthcare workers (HCWs) of the modern rules could be a challenge that was found with normal data gatherings of the healing center. Instruction, preparation, and works out have been frequently organized since the starting of the episode for cuttingedge $\mathrm{HCW}$ s to guarantee that all $\mathrm{HCW}$ s caring for patients get satisfactory data and prepare on personal protective equipment (PPE) and clinical administration of the patients. Amid epidemics, facilitated and multidisciplinary administration between pros in infectious diseases (IDs), ERs, and infection prevention and control (IPC), conjointly hospital administration is of vital significance to supply ideal care [5].

\subsection{Anticipating the pandemic}

The ER of Mitra Delima Hospital had seven bedrooms before March 2020, but as the pandemic developed, more beds were added (11 beds standby) and ER room being divided into two rooms (for COVID an non COVID patients). Best endeavors must be made to disconnect patients with suspected or affirmed COVID19 [6].

Screening tools like screening form for ER patients and checking all suspected COVID patients with rapid test antibody was being used to date and it brought consequences in the changing flow of the patients. To date, real - time invert transcription - polymerase chain response (RT - PCR) in respiratory tests is the current gold standard strategy for the diagnosis of COVID - 19. In any case, molecular testings are time-consuming and require specialized operators, components that constrain their utilize in genuine life when the quick conclusion is required for quick intercession choices [7].

The support of the hospital management staff was necessary during this pandemic. Including internal staff to ER to bargain with COVID-19 was one arrangement 
that's taken in arrange to guarantee that healthcare was not disturbed and that specialists were not diverted from their missions.

\subsection{Logistical Matters}

Increasing expenses in PPE in Mitra Delima Hospital was also being noticed in this pandemic (March-August) as in Table 2. COVID-19 is for the most part spread by beads ousted by hacking or wheezing. Fecal or directcontact defilement may moreover happen. ER staff ought to utilize standard contact and bead safety measures, counting confinement gowns, gloves, masks, and eye protection (shields or goggles).

Table 2. Expenses in PPE during COVID-19 Pandemic

\begin{tabular}{|c|c|}
\hline Month & Expenses in PPE \\
\hline March & Rp. 40.614 .399 \\
\hline April & Rp. 13.500 .000 \\
\hline May & Rp. 15.854 .484 \\
\hline June & Rp. 35.973 .310 \\
\hline July & Rp. 35.780 .540 \\
\hline Augusts & Rp 78.224.264 \\
\hline
\end{tabular}

\section{CONCLUSIONS}

Most health services, especially ER Mitra Delima Hospital, will face an increase in COVID-19 patients and must anticipate the consequences, including increasing the number of beds, personnel, and policy changes to guarantee the commitment of hospital management staff in arrange to make strides the hospital's flexibility to calamities, advance viable authority, and give a more organized communication way for the community and approach producers.

\section{AUTHORS' CONTRIBUTIONS}

TK: concept and design the study, data analysis, writing; AYN: data analysis, data collection, writing; DK: data collection, writing

\section{ACKNOWLEDGMENTS}

The authors thank to Mitra Delima Hospital, staff, and all participants that support and involved in this study.

\section{REFERENCES}

[1] Ortiz-Barrios M, Gul M, López-Meza P, Yucesan M, Navarro-Jiménez E. Evaluation of hospital disaster preparedness by a multi-criteria decision making approach: The case of Turkish hospitals. Int J Disaster Risk Reduct. 2020;49(March).

[2] World Health Organization. Weekly Epidemiological Update on COVID-19.
2020;(October). Available

from: https://www.who.int/docs/defaultsource/coronaviruse/situation-reports/20201012weekly-epi-update-9.pdf

[3] LeCraw FR. Rapid adoption of resilience strategies during the COVID-19 pandemic. J Patient Saf Risk Manag. 2020;25(4):163-6.

[4] Gardner AK, DeMoya MA, Tinkoff GH, Brown KM, Garcia GD, Miller GT, et al. Using simulation for disaster preparedness. Surg (United States) [Internet]. 2016;160(3):565-70. Available from: http://dx.doi.org/10.1016/j.surg.2016.03.027

[5] Peiffer-Smadja N, Lucet JC, Bendjelloul G, Bouadma L, Gerard S, Choquet $\mathrm{C}$, et al. Challenges and issues about organizing a hospital to respond to the COVID-19 outbreak: experience from a French reference centre. Clin Microbiol Infect [Internet]. 2020;26(6):669-72. Available https://doi.org/10.1016/j.cmi.2020.04.002

[6] Kliger AS, Silberzweig J. Mitigating risk of COVID-19 in dialysis facilities. Clin J AmSoc Nephrol. 2020;15(5):707-9.

[7] Cassaniti I, Novazzi F, Giardina F, Salinaro F, Sachs M, Perlini S, et al. Performance of VivaDiag COVID-19 IgM/IgG Rapid Test is inadequate for diagnosis of COVID-19 in acute patients referring to emergency room department. J Med Virol. 2020;92(10):1724-7. 